\title{
Evaluation of the Organic Carbon Content in the Low-Permeability Shale Formations (As in the Case of the Khadum Suite in the Ciscaucasia Region)
}

\author{
V.YU. KERIMOV, R.N. MUSTAEV and A.V. BONDAREV \\ Gubkin Russian State University of Oil and Gas (National Research University), \\ Building 1, 65 Leninsky Prospekt, Moscow, 119991, Russia. \\ http://dx.doi.org/10.13005/ojc/320648
}

(Received: October 18, 2016; Accepted: November 24, 2016)

\begin{abstract}
The objective of the study is to evaluate the initial content of organic carbon, which is lost in the hydrocarbon generation and catagenesis. It is required for the reliable evaluation of source rock generation potential. The greater the differences between the contemporary and initial values of organic carbon, the greater the maturity of the source rock. Due to the catagenetic consumption of organic substance for the formation of hydrocarbons and non-hydrocarbon products, there is a reduction in the mass of organic substance during the catagenesis, and at every stage of transformation we deal with the residual concentrations. To restore the original values of organic carbon by the beginning of catagenesis, i.e. by the beginning of $\mathrm{HC}$ generation, we recommend using the conversion factors that take into account both the type and concentration of substance, as well as the catagenesis gradations, reached by the oil source deposits. As a result of calculations, it was determined that the original concentrations of organic carbon in Bajocian-Bathian clays is 2.7$3.12 \%$, in the Aptian-Albian deposits -3.9 to $4.4 \%$, in the deposits of the Khadum suite $-3-5.5 \%$. Due to that, the average hydrocarbon potential was increased 1.5-2 times. Based on the results of initial source rock state recovery, we have made a map of initial organic carbon content that allows us to give a reliable estimate of generation potential for the source rocks of the Khadum suite, and to determine the perspectives of hydrocarbon accumulations exploration in the low-permeability shale formations of Ciscaucasia.
\end{abstract}

Keywords: Organic carbon, Catagenesis, Generation, Hydrocarbon, Generation potential, source rock, Khadum suite, shale formations.

\section{INTRODUCTION}

The nonconventional $\mathrm{HC}$ resources in the low-permeability shale formations are associated with the regions of immature potentially "rich" and "very rich" oil source rocks development that are at the initial stage of major oil generation phase or on the approaches to it. The main criterion for searching the shale $\mathrm{HC}$ is not a trap, where the $\mathrm{HCs}$ are accumulated and the deposits are formed, but directly the rocks, where the HCs were formed, but their emigration did not happen ${ }^{3-5}$. The practical 
interest for prospecting and exploration of oil and gas accumulations in the low-permeability shale clay formations may present the enriched OMs. The number of TOC usually reaches values of $2 \%<$ TOC $<10 \%$. The higher is TOC, the greater the productive potential of shale low-permeability clay formations. However, as evidenced by the geochemical surveys, the organic matters contained in the shale low-permeability reservoirs often are relatively immature and are at the stage of early oil generation. The hydrocarbon generation also occurs in such formations, which have not reached a sufficient depth of immersion and temperature peak $^{1}$. Thus, TOC is the most important parameter in the evaluation of $\mathrm{HCs}$ resources of shale reservoir. The hydrocarbons recoverable from the oil and gas bearing shale will be contained in the formation with such concentration, which has arisen as a result of their generation in situ. The subject of forecasting and searching should be the oil and gas bearing plays.

As the oil and gas bearing shales, the authors of the article consider a number of solid, multilayered pelitic rocks (clay, marl, clayey limestone, mudstone, siltstone and shale itself), which enclose all possible forms of $\mathrm{OM}$, reflecting the stages of its maturity ${ }^{6}$. Differing from the other pelitic rocks by textural characteristics, the shales can be cleaved into plates. An important distinctive feature ${ }^{8}$ of accumulations in the shale and tight reservoirs is that the HCs have the dispersed state in the rocks with low permeability matrix ${ }^{10}$. In such rocks, the oil and gas have mainly the diffusely dispersed state in the microcracks.

In addition to the above features, these formations are characterized by: increasing clay content of cuts in the direction of folding immersion - from the sides to the central parts of depressions and deflections, decreasing reservoir properties, increasing dispersion degree of the terrigenous material, growing content of silt and pelitic fractions in the particle size composition, decreasing porosity and increasing pore tortuosity; reduction in the capacity and consistent wedging out of cut components from the central portions of basin to their peripheral framing, and, due to that, the formation of deadlock hydrodynamic sections (lenses, "pockets"); development of predominantly clay fraction in the central portions of basin; and decreasing fracturing of carbonate intervals along the immersion, i.e. lenticular substantially shape of reservoirs, where the probability of any significant fluids motion along the Elysion model is rather limited.

The objective of the studies is to evaluate the initial content of organic carbon that is lost during the hydrocarbon generation and catagenesis, which is required for a reliable evaluation of source rock generation potential.

\section{Research methods}

One of the main parameters, characterizing the petroleum bearing rocks (PBRs), is the total organic carbon content (TOC). According to various researchers, different values of the PBRs concentration limits are allocated ${ }^{13-15}$. Most researchers consider the contribution of deposits, containing TOC $<1 \%$, as negligible in the formation of oil and gas bearing potential of subsoils and do not consider them as the HCs sources. In the Russian practice, they use the values of TOC $>0.1 \%$ in the carbonate rocks and TOC $>0.2 \%$ in clayey rocks, as sufficient to classify deposits as the PBRs because at those TOC contents the desorption of bitumenoids occurs, and they are able to emigrate.

Within the Terek-Caspian trough, the PBRs are highlighted in the following deposit complexes: Middle Jurassic, terrigenous (Bajocian- Bathian); Aptian-Albian, terrigenous, Paleocene-Eocene (Kuma horizon); Oligocene (Khadum suite). For the platform part of the studied area the PBRs are highlighted in the following deposit complexes: Middle Jurassic, terrigenous (Bajocian- Bathian); Aptian-Albian, terrigenous; Oligocene (Khadum and Batalpashinsk suites).

The conducted studies indicate the high oil source properties and allow to highly consider the prospects of searches of both conventional and unconventional (shale) $\mathrm{HCs}$ resources of the Khadum deposits in the Central and East Caucasus region. According to the results of chemical-bitumenological studies by various authors $2,7-8,12$, etc, the TOC content in the samples of Khadum and Batalpashinsk deposit is ranged from $0.26 \%$ (psheh limestones in the well Dovsunskaya-4) to $8.35 \%$ (clays of the Ostracoda horizon in the well Emelyanovskaya-1). The modal TOC value for all samples, studied by the pyrolytic 
method using Rock-Eval analyzer (226 samples), is $2.11 \%$. The average TOC content value for Khadum rocks is $2.26 \%$. With increasing degree of the carbonation of rocks, the TOC content is reduced. Minimum values are marked for limestone (0.25\%). The highest average TOC values are characteristic of clay and marl of the Ostracoda horizon- $4.46 \%$. The regularities of the change in TOC concentrations along the area of the studied region are shown in Fig. 1. The scheme in Fig. 1 shows that the area of maximum TOC values (3-4\%) extends diagonally from the northwest centroclinal of the Terek-Caspian trough (Soviet, Kursk area) in the north-east towards the East Manych trough through the central part of the shaft Prikumsk (Achikulak, Yemelyanovsky, and Novomolodezhnaya areas). Some local maxima of TOC concentrations (about 2-3\%) are observed in the eastern parts of the Terek-Sunzha folded zone (Oktyabrskaya and Khankalskaya areas) and foothills of Dagestan (Dimitrov area).

Khadum deposits of the Eastern and Central Ciscaucasia can be characterized primarily as "rich" (TOC e" 1-3\%) and "very rich" (TOC > 3\%) source rocks. The zone of "very rich" oil source Khadum deposits crosses the study area by a narrow diagonal stripe in the direction from south-west to north-east. There, TOC reach up to $4 \%$ and more. Some local areas of "very rich" Khadum PBRs are also fixed within the Terek-Sunzha region. In the predominant part of the study area, studied deposits can be classified as "rich" PBRs. Only in some local areas (north-west of the Stavropol arch framing, framing the western Caspian Sea, the western part of Sulak cavity) studied deposits are classified as "average" by the TOC content (less than 1\%) of source rocks.

For a reliable evaluation of source rock generation potential, it should be considered that during the $\mathrm{HCs}$ generation and catagenesis those rocks lose a part of their initial TOC content. And the more differences between the contemporary and initial TOC values, the greater the maturity of the source rock. The total organic carbon can be conditionally divided into two parts - capable to conversion into the $\mathrm{HCs}$ and the part that does not generate the $\mathrm{HCs}$.
Initial values of the following geochemical parameters are used to characterize the oil source formations: $\mathrm{C}_{\text {org }}$ - percentage content of organic carbon in sedimentary rocks; $\mathrm{HI}$ (hydrogen index) - ratio of the number of generated HCs (peak S2 on the chart of Rock-Eval pyrolysis) to TOC; Type of the $\mathrm{OM}$ - the type of kerogen is mainly determined by chemical and coal petrology characteristics of kerogen.

Due to the catagenetic consumption of OMs for the formation of hydrocarbons (liquid and gas) and non-hydrocarbon products (water, gases $-\mathrm{CO}_{2}, \mathrm{H}_{2} \mathrm{~S}, \mathrm{~N}$, etc.), a reduction in the mass of OMs in catagenesis occurs, and at each stage of OM transformation we are dealing with the residual concentrations. To restore the initial values of TOC by the beginning of catagenesis, i.e. by the beginning of $\mathrm{HCs}$ generation, we recommend using the conversion factors that take into account the type and concentration of the substance, as well as catagenesis gradations, reached by the oil source rock deposits.

They are based on the material balance calculations, the concept of which is described in the writings of S.G. Neruchev et al. ${ }^{9-10}$. The concentration of $\mathrm{TOC}_{\text {init. }}$ is calculated by the following formula: $\mathrm{TOC}_{\text {init }}{ }^{*}=\mathrm{TOC}^{\text {red. }} \cdot \mathrm{C}_{\text {init. }}{ }^{\mathrm{g}} / \mathrm{C}_{\text {red }}{ }^{\mathrm{g}} \cdot \mathrm{W}_{\text {red" }}$,

where $\mathrm{TOC}_{\text {init. }}$ - the initial TOC content in the rock before the catagenesis, TOC $^{\text {red. }}$ - analytically determined TOC content in the rock, $\mathrm{C}_{\text {init. }}{ }^{\mathrm{g}}$ - carbon content in the initial OM (kerogen), $\mathrm{C}_{\text {red. }}{ }^{\mathrm{g}}$ - carbon content in the residual OM (kerogen), $\mathrm{W}_{\text {red. }}$ - residual weight.

Taking into account the type of $\mathrm{OM}$ and catagenesis to recalculate TOC of the Jurassic PBRs, the conversion factors 2.66 and 3.16 have been used within the Terek-Sunzha zone and the platform part of section, respectively; for the Cretaceous PBRs, Khadum-Batalpashinsk PBRs within the platform part-1.43-2.32; within the TerekCaspian trough $-2.66^{11}$.

\section{The results of the studies}

According to the result of the calculations made, it was determined that the original 
concentration of OM in Bathian-Bajocian clays is $2.7-3.12 \%$ (the mean value is $2.9 \%$ ), in the AptianAlbian deposits -3.9 to $4.4 \%$ (the mean value is $4.15 \%$ ), in the deposits of the Khadum suite $-3-5.5 \%$ (the mean value is $4.7 \%$ ). To restore the initial values of $\mathrm{HI}$, we have used the charts of kerogen evolution during the catagenesis (with HI-Tmax parameters) depending on the type of the organofacies of OM.

Table 1: Initial geochemical simulation parameters for the Terek-Caspian trough ${ }^{11}$

\begin{tabular}{lccc}
\hline PBR & TOC, \% & $\begin{array}{c}\text { mg of } \\
\text { HC/g TOC }\end{array}$ & $\begin{array}{c}\text { Type } \\
\text { of OM }\end{array}$ \\
\hline $\mathrm{P}_{3}-\mathrm{N}_{1}{ }^{1}$ & & 445 & II \\
$\mathrm{P}_{2-3}$ & 1.5 & 500 & II \\
(Khadum + Kuma) & 4.7 & & \\
$\mathrm{~K}_{1}$ & 4.1 & 500 & II - III \\
$\mathrm{J}_{2}$ bj-b & 3 & 350 & II-III \\
\hline
\end{tabular}

According to Pepper A.S. \& Corvi P.J., depending on the depositional environment, we can allocate 6 organofacies (A, B, C, D, E, F), corresponding to the existing types of kerogen. Being based on the specifics of organic matter accumulation, the Paleogene PBRs allocated within the Eastern Pre-Caucasus region have been classified as "B" organofacies. The mean values of $\mathrm{HI}$ for the Jurassic

Table 2: Initial geochemical simulation parameters for the platform part of the study area ${ }^{11}$

\begin{tabular}{lccc}
\hline PBR & TOC, \% & $\begin{array}{c}\text { mg of } \\
\text { HC/g TOC }\end{array}$ & $\begin{array}{c}\text { Type } \\
\text { of OM }\end{array}$ \\
\hline $\mathrm{P}_{32-3}$ & 2.8 & 440 & II \\
$\mathrm{K}_{1}$ & 2.2 & 350 & $\mathrm{II}$ \\
$\mathrm{J}_{2}$ bj-b & 1.5 & 250 & $\mathrm{II}$ \\
\hline
\end{tabular}

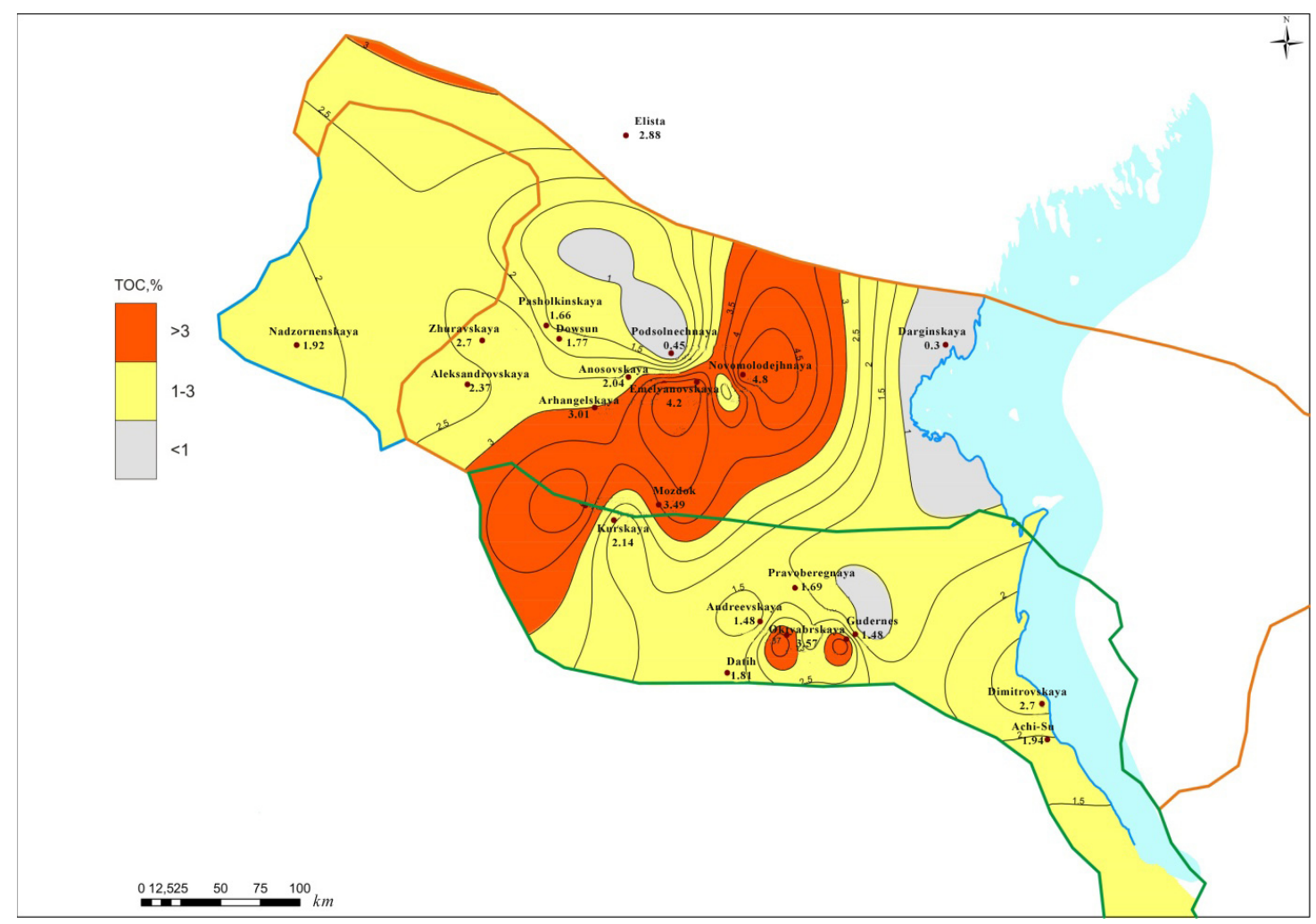

Fig. 1: Classification plan according to the TOC content in Khadum deposits, Central and East Ciscaucasia region 
PBRs were 250-350 mg of $\mathrm{HC} / \mathrm{g}$ TOC, Aptian-Albian -300 to $500 \mathrm{mg} \mathrm{HC} / \mathrm{g} \mathrm{TOC}$, Maikop formations - up to $450 \mathrm{mg}$ of $\mathrm{HC} / \mathrm{g}$ TOC.

The initial values of geochemical parameters for the main oil source formations are shown in Tables 1 and 2.
Knowing the current values of the OM content in the source rock, hydrogen index, degree of $\mathrm{OM}$ transformation and value of $\mathrm{S}_{1}$, one can calculate the initial values of TOC and $\mathrm{HI}$. The charts shown in Fig. 2 present the results of geochemical parameters recalculation. Some of the available data on the Terek-Caspian trough is recalculated to the initial

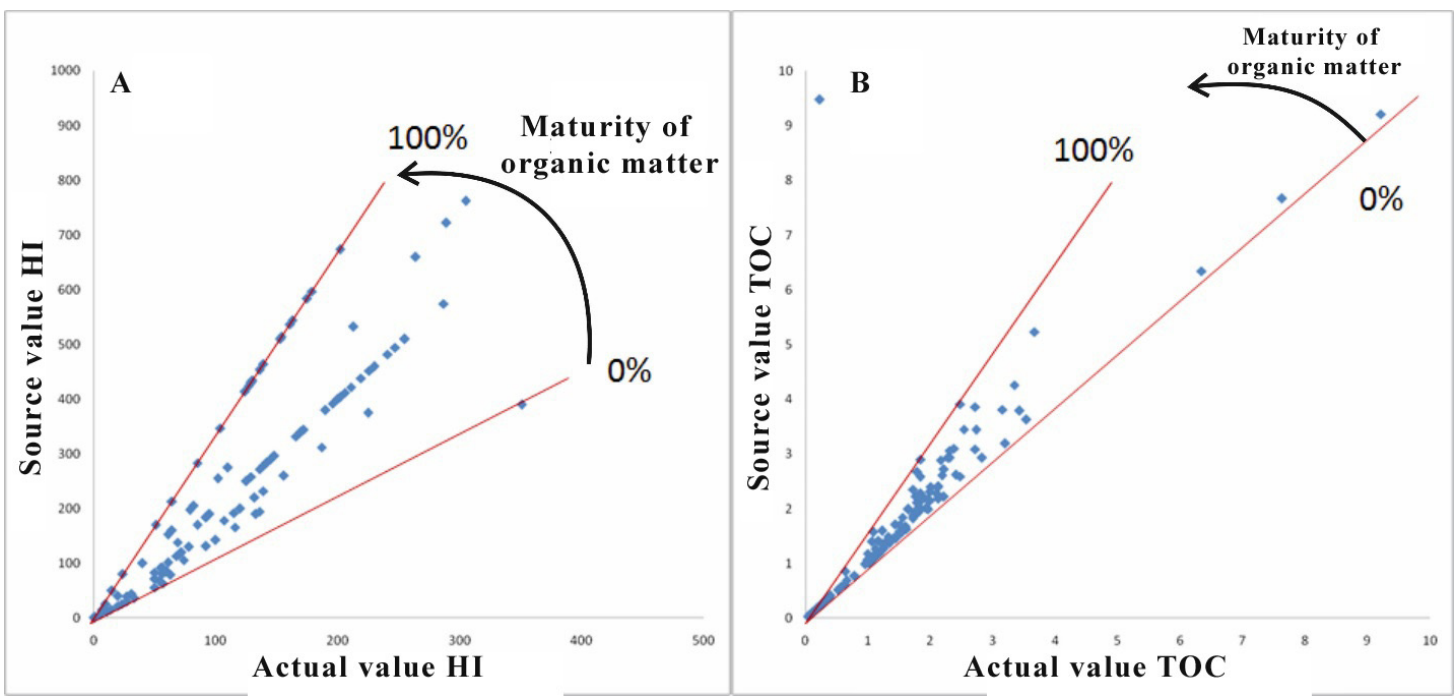

Fig. 2: Recalculation of geochemical parameters of the Khadum suite:

A) hydrogen index values; B) TOC values.

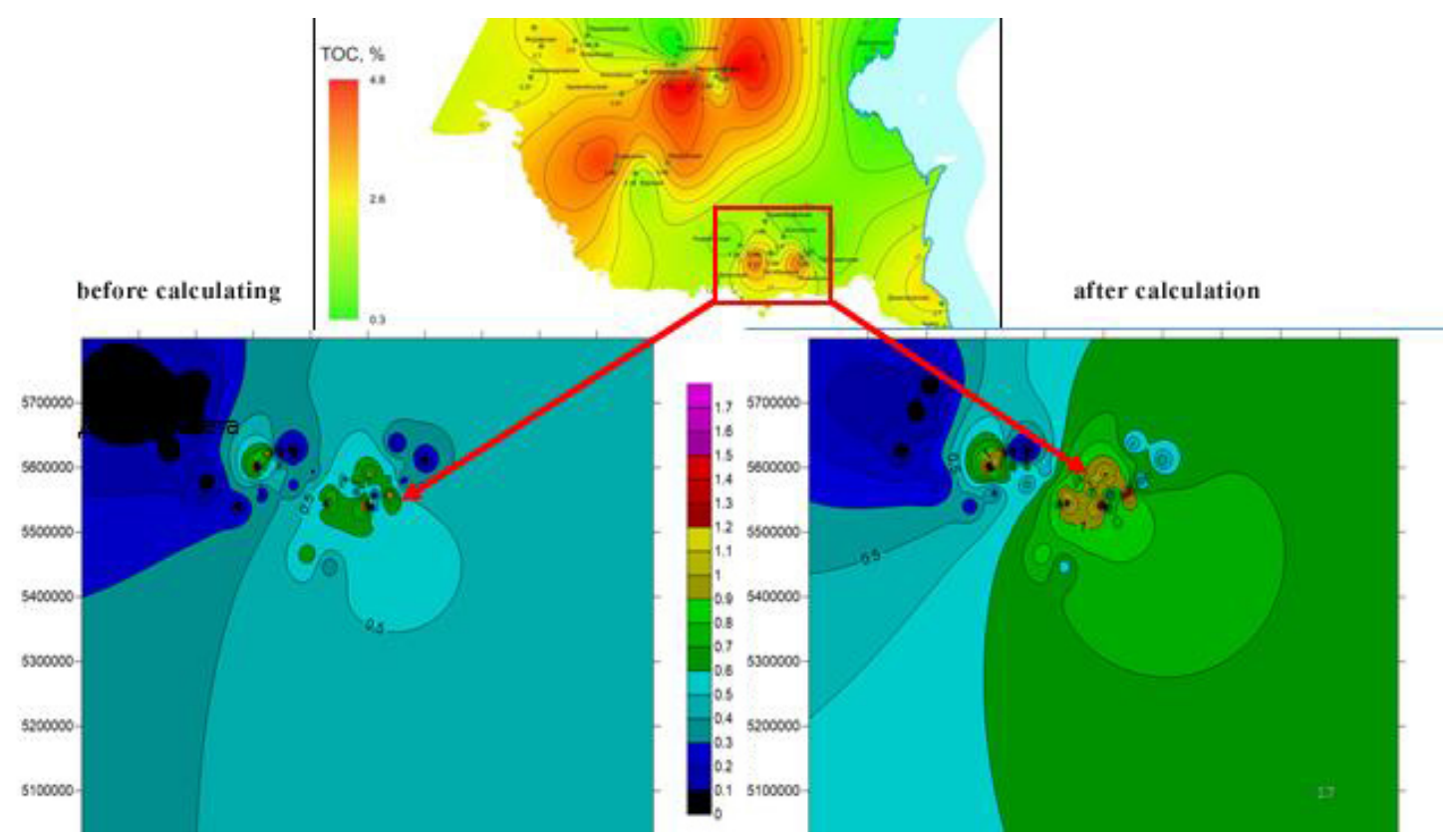

Fig. 3: Maps of TOC content before and after the recalculation of initial TOC values in the Khadum deposits 
geochemical properties, depending on the relative maturity of specimen. The line, corresponding to the immature specimens $(0 \%)$, TOC and $\mathrm{HI}$ values have remained unchanged. The line corresponds to the maximum mature samples (100\%), where the effect of recalculation is the highest.

Based on the results of source rock initial state recovery, we have made a map of the initial content of TOC \% (Fig. 3). Due to that, the average hydrocarbon potential has increased 1.5-2 times. The similar calculations were made for the wells of the Terek-Caspian trough, as there is a complete set of essential geochemical information about them.

\section{DISCUSSION}

Typically, the different types of kerogen have different generation ability. The first type is able to be almost completely recycled into $\mathrm{HC}$ in the catagenesis process, while the third type of kerogen, on the contrary, for the most part consists of not generating parts and gives a little $\mathrm{HC}$. If we compare the source rocks, represented by different types of kerogen but with the same initial TOC content at the time of the maximum maturity, we can see that the kerogen which generated the largest number of $\mathrm{HC}$ is most weakly expressed in the TOC value, because of what its significance might be underestimated. As a result of transformation, the kerogen, capable of generating the heaviest hydrocarbons, has the lowest current TOC value. And vice versa, the kerogen which formed the least amount of hydrocarbons is presented in the modern composition by the highest values of TOC. By identifying the type of kerogen, it is possible to assume how many TOC will be converted into HCs: type I - up to $80 \%$, type II - up to $50 \%$ and type III - up to 20.

The conversion factor, taking into account the type of kerogen, thermal maturity of OMs in the oil/gas source rock and chemical elements presented in the kerogen. The conversion factor was introduced in the work [16]. Usually, the adopted mean statistical value of the conversion factor equal to $1.2-1.4$ is used.

The hydrogen index $(\mathrm{HI})$ received as a result of pyrolytic analysis by the Rock-Eval method, allows to evaluate the generating features of kerogen, expressed in $\mathrm{mg} \mathrm{HC/g} \mathrm{TOC.} \mathrm{Thus,} \mathrm{the} \mathrm{analysis} \mathrm{of}$ $\mathrm{HI}^{\circ}$ for the unconventional reservoirs of shale gas in the USA, on average are estimated at $533 \mathrm{mg} \mathrm{HC} / \mathrm{g}$ $\mathrm{TOC}^{17}$. In the shales of marine origin, the $\mathrm{HI}^{\circ}$ values are varied: in $90 \%$ of the studied shale - over $340 \mathrm{mg}$ $\mathrm{HC} / \mathrm{g} \mathrm{TOC}$, in 50\% - more than $475 \mathrm{mg} \mathrm{HC} / \mathrm{g}$ TOC, and only $10 \%$ have exceeded $645 \mathrm{mg} \mathrm{HC} / \mathrm{g}$ TOC.

Assuming that the source rocks generate hydrocarbons, which constitute about $85 \%$ of the carbon, the maximum $\mathrm{HI}$ can be estimated by the inverse relation $1 / 0.085$, or $1177 \mathrm{mg} \mathrm{HC} / \mathrm{g}$ TOC. Using $1177 \mathrm{mg} \mathrm{HC} / \mathrm{g} \mathrm{TOC}$ as the maximum $\mathrm{HI}$, it is possible to calculate the percentage of generating organic carbon from the initial hydrogen index: $\mathrm{HIO} / 1177$. For example, if $\mathrm{HI}$ of the shale formation Barnett is estimated as $434 \mathrm{mg} \mathrm{HC} / \mathrm{g} \mathrm{TOC}^{17}$, then by means of division by $1177 \mathrm{mg} \mathrm{HC} / \mathrm{g}$ TOC we obtain organic carbon value in immature shales, that is, $37 \%$ of the TOC may be converted into oil. Thus, for a simplified calculation of percentage content of the generating organic carbon (GOC), depending on the values of initial hydrogen index, taking the maximum possible hydrogen index equal to 1177 , Jarvie ${ }^{17}$.

The content of generated organic carbon and TOC provides the key to understanding the $\mathrm{HC}$ generation and $\mathrm{OM}$ changes development. If the $\mathrm{HI}$ is known, the percentage of generating organic carbon can be easily determined by dividing $\mathrm{HI}$ by 1177. The generation factor is inversely related to the hydrogen index, it decreases with the growth of the latter. There is no doubt that the ratio of $\mathrm{HI}$ and the generation factor depends on the purity of experiment, conditions laid down in the experiments carried out, and the use of different types of pyrolysis tests: Rock-Eval or Hydrous pyrolysis ${ }^{18}$.

\section{CONCLUSION}

Thus, the organic carbon - TOC is an important parameter in the evaluation of hydrocarbon resources of shale reservoir. For a reliable evaluation of source rock generation potential, it should be considered that those rocks in the process of hydrocarbon generation and catagenesis lose part of their initial TOC content. And the greater the differences between the modern and original TOC values, the greater the maturity of source rock. Knowing the current value of OM content in 
the source rock, hydrogen index, degree of OM transformation and value $\mathrm{S} 1$, one can calculate the initial values of TOC and HI. The total organic carbon can be conditionally divided into two parts - capable to convert into the HCs and the part that does not generate the HCs. For a simplified calculation of percentage content of the generating organic carbon (GOC), depending on the values of initial hydrogen index, one should take into account the conversion factor, type of kerogen, thermal maturity of OMs in the oil/gas source rock and chemical elements presented in the kerogen. According to the result of the calculations made, it was determined that the original concentration of $\mathrm{OM}$ in Bathian-Bajocian clays is $2.7-3.12 \%$ (the mean value is $2.9 \%$ ), in the Aptian-Albian deposits -3.9 to $4.4 \%$ (the mean value is $4.15 \%$ ), in the deposits of the Khadum suite $-3-5.5 \%$ (the mean value is $4.7 \%$ ). Due to that, the average hydrocarbon potential was increased 1.5-2 times. Based on the results of initial source rock state recovery, we have made a map of initial organic carbon content that allows to give a reliable estimate of generation potential for the source rocks of the Khadum suite, and to determine the perspectives of hydrocarbon accumulations exploration in the low-permeability shale formations of Ciscaucasia.

\section{REFERENCES}

1. Anan'ev, V.V.; Smelkov, V.M.; Pronin, N.V. Oil and gas geology, 2007, 1, 32-38.

2. Bazhenov, O. K.; Fadeev, N.P. GEOS, 2005, 54-58.

3. Kerimov, V.Yu.; Mustaev, R.N.; Dmitrievskiy, S.S.; Yandarbieva, N.Sh.; Kozlova, E.V. Neftyanoe khozyaystvo, 2015, 10, 50-53.

4. Kerimov, V.Yu.; Shilov, G.Ya.; Mustaev, R.N.; Dmitrievskiy, S.S. Neftyanoe khozyaystvo, 2016, 2, 8-11.

5. Kerimov, V.Yu.; Mustaev, R.N.; Senin, B.V.; Lavrenova, E.A. Neftyanoe khozyaystvo, 2015, 4, 26-29.

6. Kerimov, V. Yu.; Mustaev, R. N.; Serikova, U. S.; Lavrenova, E.A.; Kruglyakova, M. V. Neftyanoe khozyaystvo, 2015, 3, 56-60.

7. Kerimov, V.Yu.; Lavrenova, E.A.; Mustaev, R.N.; Serikova, U.S. Neftyanoe khozyaystvo, 2015, 1, 5-17.

8. Morariu, D.; Aver'yanova, O.Yu. Neftegazovaya geologiya. Teoriya i praktika, 2013, 8(1), 22.

9. Prishchepa, O.M.; Averyanov, O.Yu.; Ilyinskiy, A.A.; Morariu, D. FSUE "VNIGRI", 2014.

10. Abrams, M.A.; Apanel, A.M.; Timoshenko, O.M.; Kosenkova, N.N. AAPG Bulletin, 1999, 83(4), 553-577.
11. Pelet, R. Rev. d'Institut Francais du Pétrole, 1985, 40(5), 551-56.

12. Yandarbiyev, N.S.; Kozlova, E.V.; Mustaev, R.; Odintsova, K.Y. In Geomodel 2015 17th Scientific-Practical Conference on Oil and Gas Geological Exploration and Development, 2015.

13. Kerimov, V.Y.; Osipov, A.V.; Mustaev, R.N.; Monakova, A.S. 16th Science and Applied Research Conference on Oil and Gas Geological Exploration and Development, GEOMODEL, 2014.

14. Kerimov, V.Yu.; Serikova, U.S.; Mustayev, R.N.; Guliyev, I.S. Neftyanoe Khozyaystvo Oil Industry, 2014, 5, 50-54.

15. Guliev, I.S.; Kerimov, V.Yu.; Mustaev, R.N. Doklady Earth Sciences, 2016, 471(1), 168-171.

16. Tissot, B.P.; Welte, D.H. Springer, 1984.

17. Jarvie, M.D. AAPG Memoir, 2012a, 97, 69-87.

18. Lewan, M.D. Comparison of oil generation kinetics for oil shales as determined by RockEval and hydrous pyrolysis. 27th Oil Shale Symposium, 2007. 